\title{
HONG KONG'S AUTONOMY UNDER “ONE COUNTRY, TWO SYSTEMS” PRINCIPLE: CHALLENGING THE CONCEPT OF OBLIGATION IN INTERNATIONAL LAW
}

\begin{abstract}
Summary
The Law of the People's Republic of China on Safeguarding National Security in the Hong Kong Special Administrative Region was passed in June 2020 provoking the global outcry. The aim of this paper is to assess the compliance of the said law with the sources of international law, which are most relevant for the assessment of the problematic points of new legislation. In providing the analysis, the paper will not be focused only on the sources of international law, which are currently applicable. Instead, the previous relevant legal framework will also be taken into consideration where appropriate.

Keywords: new Chinese national security law, Hong Kong, Joint Declaration, international law, human rights, International Covenant on Civil and Political Rights.
\end{abstract}

\section{Introduction}

The Law of the People's Republic of China on Safeguarding National Security in the Hong Kong Special Administrative Region was passed by the Standing Committee of the National People's Congress of the People's Republic of China on June 30, 2020. It is commonly referred to as the new Chinese national security law, while its territorial application includes Hong Kong. It is noteworthy that neither the colonial government under the British rule nor the competent authorities of Hong Kong in 2003 succeeded in attempts to enact security legislation (Yunxin, 2020, p. 1497).

The said law gave rise to the debate on its legality, which significantly divided scholars and other professionals. While some authors including Chen argue that this law is a legal and legitimate measure to safeguard China's national security (Xinhua, 2020, p. 1), the others such as Tai claim the opposite labeling the law as "controversial" and "sweeping" (BBC, 2020; Clift, 2020, p. 17). Those praising the new Chinese national security law based their argumentation on the fact that Hong Kong has failed to adopt the national security legislation over the past 23 years, even though the Basic Law provides a clear legal

\footnotetext{
${ }^{*} \mathrm{PhD}$, Senior Research Fellow, Institute of Comparative Law, Belgrade, Serbia, e-mail:vesnacoric@yahoo.com

${ }^{* *} \mathrm{PhD}$, Faculdade de Direito, Universidade de Sao Paulo, Brazil; Fernandez \& Jankov Legal Intelligence, Brazil, Portugal, Serbia, e-mail:fernandez.jankov@fernandezjankov.eu
} 
ground for Hong Kong to enact laws against behaviors which endanger national security. According to them, therefore, the new law helps restoring order, prosperity and stability in Hong Kong, which was unreachable in the absence of the national security legislation.

On the other hand, some opponents of the new law (Ni Aolain, 2020; Colville, 2020) expressed concerns about various controversial points of the new law, given that they pose a serious risk that the freedom of opinion, freedom of expression and freedom of peaceful assembly as well as some other rights and freedoms may be infringed upon.

However, it seems that the arguments brought by the critics thus far have not been comprehensively and systematically addressed and therefore lack a scientific foundation. As to address the given limitations, this article aims at assessing whether the new Chinese national security law is in line with the main obligations to which China is subject, based on the mechanisms set by international law, more specifically by the sources of international law as referred to in Article 38 of the Statute of the International Court of Justice.

After presenting the mechanism against which the new Chinese national security law will be assessed, the paper will deal more with the compliance of the national legislation with the sources of international law, which are the most relevant for the examination of the controversial points of new legislation. In providing the analysis, the paper will follow the evaluative approach, thus not being limited only to the sources of international law, which are currently applicable. Instead, the previous relevant legal framework will also be taken into consideration where appropriate.

\section{Sources of International Law Relevant to the Evaluation of the Legality of the New Chinese National Security Law}

In order to provide an assessment of the legality of the new Chinese national security law, the sources of international law as referred to in Article 38 of the Statute of the International Court of Justice shall be taken into consideration. According to Article 38(1) of the Statute of the International Court of Justice:

"1. The Court, whose function is to decide in accordance with international law such disputes as are submitted to it, shall apply:

a. international conventions, whether general or particular, establishing rules expressly recognized by the contesting states;

b. international custom, as evidence of a general practice accepted as law;

c. the general principles of law recognized by civilized nations;

d. subject to the provisions of Article 59, judicial decisions and the teachings of the most highly qualified publicists of the various nations, as subsidiary means for the determination of rules of law[...]"

Brownlie (1998, p. 3) argues that Article 38 is considered as a 'complete statement of the sources of international law', although the given article does not explicitly refer to 'sources'. He further adds that in practice the International Court of Justice may be expected to observe the order in which they appear. In that regard, Brownlie specifies that 
international conventions and international customs are obviously the important sources of mutual obligations of the parties. Brownlie further states that general principles of law perhaps can also be considered as formal sources, opposite to the fourth category which relates to material sources.

On the other hand, it seems that Khan $(2019$, p. 1$)$ rightly observes that Article 38 is not a complete reference point for the sources of international law as it does not include, among others, ius cogens norms. Khan further states that Articles 53 and 64 of the Vienna Convention on the Law of Treaties should be interpreted as proving the existence of ius cogens as an external source outside Article 38. In that context, he argues that if ius cogenes would have been perceived as a customary law it would conflict with the reached consensus according to which there is no hierarchy among the sources of Article 38. More specifically, Khan claims that the balance of hierarchy of sources of international law from Article 38(1) of the Statute will be hindered, if ius cogens is considered as a customary law given that Article 53 of Vienna Convention on the Law of Treaties gives ius cogens an authoritative status.

In the evaluation of the new Chinese national security law, the most attention will be paid to the international treaties, as they constitute the most prominent source of international law. Both bilateral treaties which are relevant for the status of Hong Kong and multilateral treaties specifically governing human rights related commitments of Hong Kong will be examined.

Given that China has not yet ratified the United Nations International Covenant on Civil and Political Rights (hereinafter: ICCPR) whose provisions are of great importance for protection of fundamental rights which are allegedly endangered by the new Chinese national security law, the other sources of international law such as an international custom will also be taken into due account. Before starting to assess compliance of the new Chinese national security law with the given sources of international law, the brief historical overview of relations between the United Kingdom and China with regard to Hong Kong will be provided as critical for understanding its legal background as well as the current state of the play. In the upcoming assessment, it is important to keep in mind that the application of reparations based on State Responsibility does constitute a natural consequence of the principle pacta sunt servanda as well as that it arises from the breaches of ius cogens (Triggs, 2006, p. 507) and other rules of general international law (Crawford, 2002, p. 127).

\section{Legal Background of UK - Hong Kong Relations}

The handover of Hong Kong refers to the historic transfer of sovereignty over Hong Kong, which took place between the United Kingdom and China on July 1, 1997. It amounted to the end of administration over the colony of Hong Kong by the United Kingdom and its return to the territory of China as a special administrative region (Chui, Tsang \& Mok, 2010, p. 52). Hong Kong has carried on maintaining the governing and economic systems separate from those of China (Gadhok, 2020, p. 1). 
The said handover terminated 156 years of British colonial rule in Hong Kong. The main legal documents relative to the colonial history of Hong Kong are three treaties concluded between the Great Britain and Qing Empire governing how Great Britain obtained and gradually extended control over the territory of Hong Kong. While the 1842 Treaty of Nanking and 1960 Convention of Peking were concluded in the aftermath of the First and Second Opium Wars, the third treaty was signed afterwards. ${ }^{1}$ In 1984, the Sino-British Joint Declaration (hereinafter: Joint Declaration) was signed by Great Britain and China having spelled the end of British colonial rule and marked the beginning of the handover process that concluded in 1997 (Wong, 2018, p. 314; Kutlešić, 2019, p. 10). It constitutes a bilateral international treaty expressing the general agreement that the common goal of the government of the United Kingdom and the government of China is for China to resume authority over Hong Kong on July 1, 1997.

The Joint Declaration is considered as the precursor to the Basic Law (Yee, 1996, p. 600; Vitrano, 1995, p. 447), given that two countries agreed in the Joint Declaration to the content of the Basic Law. In line with that, the Basic Law as a mini constitution of Hong Kong provides for the fundamental rights and duties of the Hong Kong people. These rights include, inter alia, the right to life, equality before the law, freedom from torture, personal liberty, liberty of movement, privacy of communications, religion, freedom of expression, freedom of association, and the right of peaceful assembly. In addition, pursuant to the Joint Declaration which guarantees the "one country, two systems" policy, the Basic Law promulgates the same policy (Yee, 1996, p. 600). Relying on the theme of the Joint Declaration, the Preamble of the Basic Law indicated that "under the principle of 'one country, two systems' the socialist system and policies will not be practiced in Hong Kong".

It appeared that all these rights have created a solid foundation for development of the rule of law and democratic society. However, the criticism was drawn in legal theory (Harris, 1986, p. 352) in relation to the fact that the Basic Law was developed by the Basic Law Drafting Commission, whose majority of members was appointed by the Government of China, while representatives of the Hong Kong people remained underrepresented. In that context, it was claimed (Vachon, 2020, p. 103) that the given composition of the Drafting Commission influenced the unclear wording of the Basic Law, which leaves flexibility for interpretations in favor of granting more authority to China. Furthermore, it has been argued (Davis, 1996, p. 308; Vachon, 2020, p. 109) that the way the Basic Law was written allows China to manipulate Hong Kong's autonomy given that there is no clear procedure indicating when the new law contravenes with the Basic Law.

\section{Assessment of Compliance of the New Chinese National Security Law with International Law}

The full and systematic assessment of compliance of the new Chinese National Security Law with international law requires equal attention to be paid to applicable bilateral and multilateral treaties as well as to other sources of international law. In order to address all the relevant issues in the well-structured manner, the compliance of the said law with the Joint Declaration as the applicable bilateral treaty will be assessed first in this 
section. Subsequent to it, the alignment with other relevant sources of international law will be examined.

\subsection{Assessment of Compliance of the New Chinese National Security Law with the Joint Declaration}

As it was explained earlier, the Basic Law does contain certain limitations. Nevertheless, it is important to mention that both the Joint Declaration and the Basic Law have been progressive in one respect. Through their provisions, the ICCPR and United Nations International Covenant on Civil and Political Rights (hereinafter: ICESCR) have remained applicable to Hong Kong (Vachon, 2020, p. 114). ${ }^{3}$ Those guarantees ensuring that the ICCPR and ICESCR will remain applicable after the transition were attributable to the joint efforts made by the Great Britain and Hong Kong in order to preclude China from applying its lower standard of human rights' protection in Hong Kong (Vachon, 2020, p. 113). While the United Kingdom (including Hong Kong) is a State Party of the ICCPR from 1976 and therefore subject to respective human rights commitments, the same was not the case with China as it still has not ratified the ICCPR. Although the reference to the ICCPR in the Basic Law and Joint Declaration is considered as a progressive step, it seems that it does not provide sufficient guarantees for achieving proper level of human rights on the ground. The new Chinese national security law also made reference to the ICCPR. However, the said provision is considered a dead letter, given that some other provisions of the same law are in conflict with the text of the ICCPR, as it will be explained later in the text.

Several problems have been identified with regard to the compliance of the new Chinese National-Security Law with the Joint Declaration. Firstly, the Joint Declaration stipulates that Hong Kong as a Special Administrative Region is under China's sovereignty. However, it further adds that Hong Kong enjoys a high degree of autonomy, which does not include "foreign and defence affairs" which are the responsibilities of China's central government. It also stipulates that Hong Kong will be vested with executive, legislative and independent judicial power, including that of final adjudication. Moreover, the Joint Declaration expressly stipulates that the maintenance of public order in Hong Kong will be the responsibility of the Government of Hong Kong as a Special Administrative Region.

In that regard, it is also relevant Article 23 of the Basic Law states that Hong Kong shall enact legislation to address subversion, secession, sedition, treason, foreign influence. However, the problem emerged as the new Chinese National Security Law was enacted by China while not by Hong Kong. Supporters of the new law argued that the law was lawfully enacted as the structure of Basic Law allows laws enacted by China to be applied in Hong Kong, provided they are listed under its 'Annex III'. While Bakers (2020) argues that the applied procedure raises constitutional questions in Hong Kong, it seems that it also affects its compliance with international law. The application of Annex III related mechanism concerning new Chinese national security law is also problematic from the standpoint of international law as Annex III laws are supposed to be the laws that concern 
foreign affairs, national defense, and other matters which are by the Joint Declaration omitted from the Hong Kong's autonomy.

It appears from those bilateral treaty provisions that national security related matters do unambiguously fall under the autonomy 'sphere' and therefore the interference of China by means of enacting the new national security law is considered illegal. Although, the Joint Declaration explicitly stipulates that human rights including the freedom of press, freedom of speech, freedom of assembly, and freedom of association will be ensured by the law of Hong Kong, that did not occur. Instead, China overtook the competencies belonging to Hong Kong and passed the new national security law. By doing so, it breached the bilateral treaty concluded with the United Kingdom that is the main legal instrument setting the framework for the relationship between the UK and China.

\subsection{Assessment of Compliance of the New Chinese National Security Law with the Sources of International Law other than Bilateral Treaties}

The mere fact that China did not ratify the ICCPR does not dispose China of obligation to ensure respect for the ICCPR in the territory of Hong Kong as it overtook the respective commitment by the Joint Declaration. Given that there is consensus that rights and freedoms contained in the Universal Declaration of Human Rights are considered customary international law, and that the ICCPR upholds the civil and political rights guaranteed in the Universal Declaration of Human Rights it can be concluded that China is also bound to comply with the rights and freedoms guaranteed by the ICCPR on its whole territory, not only in Hong Kong (Vachon, 2020, p. 119). Taking into account the scope of the ICCPR, it seems that it is the most relevant international multilateral treaty for assessing the compliance of the new Chinese National Security Law with international law.

When it comes to the alignment of the said law with the ICCPR, the Colville (2020) rightly observes that definitions of four major offences contained in the law are unnecessarily broad and vague. These are the definitions of the following crimes: separatism, subversion, terrorism and collusion with foreign countries. Those poorly defined crimes may give rise to the violation of the ICCPR, as they leave room for the discriminatory and arbitrary interpretation and enforcement of the law targeting inter alia different activities as well as they may undermine the application of the legality principle in the sense of Article 15(1) of the ICCPR.

Colville (2020) rightly observes that all the aforementioned offences and in particular the offence of "collusion with a foreign country or with external elements to endanger national security" may negatively affect the possibility for civil society actors to exercise their right to participate in public affairs. These provisions could criminalize human rights defenders and activists for the exercise of their right to freedom of expression, association and peaceful assembly what is contrary to Articles 19, 21 and 22 of the ICCPR governing respective rights and freedoms.

The provisions of the new Chinese National Security Law are not only in conflict with the UN treaty law but they are also contrary to other sources of international law. For instance, the UN experts also expressed concerns regarding the definition of terrorism 
under the national security law as it goes well beyond the UN Security Council's definition of terrorist conduct. While the UN Security Council's definition of terrorist conduct is limited to causing death or serious bodily harm, the definition under the Chinese national law extends to damage made to physical property such as transport facilities. This may serve as a clear example of the case where the international law is violated, nevertheless that the definition of terrorism is still not determined by any international treaty, which would be applicable to Hong Kong.

Moreover, the provisions of the new Chinese National Security Law also undermine the independence of Hong Kong's judiciary and negatively affect the right to a fair trail and due process as enshrined by Articles 14 and 15 of the ICCPR. Firstly, the new Chinese National Security Law envisages that Hong Kong's chief executive will now be able to handpick which judges hear security cases (Yunxin, 2020, p. 1503). Also, the new Chinese National Security Law provides that where the new security law conflicts with the existing Hong Kong law, the new law will prevail. Furthermore, the possibility of transferring cases from the jurisdiction of Hong Kong to China is considered as one of the most controversial point of the new Chinese National Security Law when it comes to safeguarding the right to a fair trial. Namely, the central government of China can intervene in national security cases, especially during crises or if a case is considered "complex". By doing so, the new Chinese National Security Law opens the door for defendants in important cases to stand trial before courts in China, where it seems that unavoidable convictions regularly come along with harsh penalties. Therefore, provisions of the law stating that the rights of suspects and defendants in national security cases should be respected turned out to be insufficient for ensuring compliance with the ICCPR.

More specifically, the new law provides for the presumption of innocence and the right to defend oneself, but does not offer additional clarifications on those protections. By doing so, the law leaves open the danger that certain harsh and unaccountable practices from China could spread to Hong Kong and become applicable to its national security suspect, such as incommunicado detention in duration of six month, torture, coerced confession, and lack of access to counsel (Hernandez, 2020, p. 1). By means of not providing enough specified guarantees for the prohibition of torture, the new law breaches not only the treaty law, including the ICCPR, but the international norm of ius cogens as well. The given law also does not guarantee a person's right to silence as an essential element of the presumption of innocence as it enables authorities to require from organizations and individuals all the information, even if the required information is self-incriminating (Amnesty International, 2020).

Finally, the law's extremely broad extraterritorial scope extending its application to non-residents intensifies its adverse effects and further spreads and provokes the worldwide criticism. Article 38 stipulates that it can be applied even to offenses committed "outside the region by a person who is not a permanent resident of the region". Clarke rightly observes that the national security law is even broader in scope than criminal law of China (Clarke according to Feng, 2020). 


\section{Conclusion}

The new Chinese national security law has caused the global outcry. From the standpoint of international law, that criticism has been fully justified, The Chinese National Security Law is in conflict with multiple sources of international law leading to violations of various rights and freedoms determined by them.

Firstly, the new Chinese national security law breaches the provisions of the Joint Declaration governing degree of autonomy available to Hong Kong excluding only "foreign and defence affairs". Moreover, the said law is in conflict with the provisions of the Joint Declaration guaranteeing protection of human rights and freedoms from the ICCPR.

Secondly, the new Chinese national security law is not in harmony with the numerous rights and freedoms including the freedom of opinion, freedom of expression and freedom of peaceful assembly as well as the right to a fair trial, which are enshrined by the ICCPR. The obligation of China to follow the ICCPR when it comes to Hong Kong is twofold. It derives from its bilateral treaty concluded with the United Kingdom as well as from the provisions of the ICCPR reflected in the international customary law.

Applying the Khan's approach (Khan, 2019), according to which the ius cogens norms do constitute a separate and external source of international law outside Article 38, it can be concluded that the new Chinese law leads not only to violations of respective international treaties and international customs, but also leads to violation of the prohibition of torture, which constitutes the ius cogens norm. The new law clearly demonstrates that mere reference to the international covenants is not sufficient for providing needed guarantees of rights, which they cover as long as those provisions are not sufficiently specified and clarified.

The flagrant violations of multiple sources of international law may be a consequence of China's wrongful prioritizing commitments or the lack of commitments deriving from the multilateral international treaties, such as the ICCPR over the commitments coming from the bilateral treaties, such as the Joint Declaration. In addition, they can be attributable to China's failure to understand that the ICCPR reflects international customary law and as such should be respected. Notwithstanding the reasons behind such China's failures, the doctrine of state responsibility should be applied under these circumstances.

\section{References}

Brock, D. G. 1992. Hong Kong. In: Platto, C. \& Horton, W. G. (eds.), Enforcement of Judgments Worldwide, pp. 18-32.

Brownlie, I. 1998. Principles of Public International Law. Fifth Edition. Oxford University Press: New York.

Chui, E., Tsang, S. \& Mok, J. 2010. After the Handover in 1997, Development and Challenges for Social Welfare and Social Work in Hong Kong. Asia Pacific Journal of Social Work and Development, 20(1), pp. 52-64.

Clift, B. 2020. Hong Kong's Made-in-China National Security Law: Upending the Legal Order for the Sake of Law and Order. Australian Journal of Asian Law, 21(1), pp. 1-23. 
Crawford, J. 2002. The International Law Commission's Articles on State Responsibility. Introduction, Text and Commentaries. Cambridge University Press.

Davis, M.C. 1996. Human Rights and the Founding of the Hong Kong Special Administrative Region: A Framework for Analysis. Columbia Journal of Transnational Law, 34(2), pp. 301-317.

Harris, K.M. 1986. The Hong Kong Accord as a Model For Dealing With Other Disputed Territories. Proceedings of the Annual Meeting (American Society of International Law), 80, pp. 348-368.

Kutlešić, V. 2019. O nekim modelima za rešenje statusa Kosova i Metohije. Strani pravni život, 64(2), pp. 5-15.

Qu, W. 2017. Translations of Early Sino-British treaties and the Masked Western Legal Concepts. Semiotica, 2, pp. 169-200.

Triggs, G. D. 2006. International law. Contemporary Principles and Practices. LexisNexis/ Butterworths.

Vachon, C. J. 2020. Hong Kong' s 1997 Transition: U.N. Enforcement Mechanisms to Guarantee Hong Kong's Human Rights Will Endure after the Transition. Denver Journal of International Law \& Policy, 28(1), pp. 97-127.

Vitrano, P. 1995. Hong Kong 1997: Can the People's Republic of China Be Compelled to Abide by the Joint Declaration. George Washington Journal of International Law and Economics, 28, pp. 445-456.

Wong, J. D. 2018. From the Treaty of Nanking to the Joint Declaration: The Struggle for Equality through State Documents. Law and Literature, 30(2), pp. 309-329.

Yee, E. 1996. Hong Kong and China in 1997: An Examination of Possible Legal and Economic Implications for United States Business. Santa Clara Law Review, 36, pp. 595-647.

Yunxin, T. 2020. The Question of 2047: Constitutional Fate of "One Country, Two Systems" in Hong Kong. German Law Review, 21, pp. 1481-1525.

\section{Website references}

Amnesty International. 2020. Hong Kong's national security law: 10 things you need to know. Available at: https://www.amnesty.org/en/latest/news/2020/07/hong-kongnational-security-law-10-things-you-need-to-know/, (4. 11. 2020).

BBC. 2020. Benny Tai: Hong Kong University fires professor who led protests. Available at: https://www.bbc.com/news/world-asia-china-53567333, (5. 11. 2020).

Colville, R. 2020. Press briefing note on China/ Hong Kong SAR. Available at: https://www.ohchr. org/EN/NewsEvents/Pages/DisplayNews.aspx?NewsID=26033\&LangID=E, (3.12.2020).

Feng, E. 2020. 5 Takeaways From China's Hong Kong National Security Law. Available at: https://www.npr.org/2020/07/01/885900989/5-takeaways-from-chinas-hong-kongnational-security-law, (6.11.2020).

Gadhok, R.S. 2020. Hong Kong's Controversial National Security Law: What Is It, Why Does China Want It?. Available at: https://www.olivegreens.co.in/easyblog/hong-kong-scontroversial-national-security-law-what-is-it-why-does-china-want-it, (2. 11. 2020). 
Hernandez, H.C. 2020. Harsh Penalties, Vaguely Defined Crimes: Hong Kong's Security Law Explained. The New York Times. Available at: www.nytimes.com/2020/06/30/ world/asia/hong-kong-security-law-explain.html, (13. 2. 2021).

Khan, I. 2019. Article 38 of the Statute of the International Court of Justice: A Complete Reference Point for the Sources of International Law?. The Newjurist, World's First International Law Magazine. Available at: https://newjurist.com/article-38-of-thestatute-of-the-international-court-of-justice.html, (5. 11. 2020).

Ni Aolain, F. 2020. UN special rapporteur on protecting human rights UN experts call for decisive measures to protect fundamental freedoms in China. Available at: https://www.ohchr.org/ EN/NewsEvents/Pages/DisplayNews.aspx?NewsID=26006\&LangID=E, (8. 11.2020).

Xinhua. 2020. China Focus: Draft decision on HK national security legislation submitted to NPC. Available at: http://www.xinhuanet.com/english/2020-05/22/c_139078396. htm, (5. 11. 2020).

\title{
Legal sources
}

Joint Declaration: Agreement on the Future of Hong Kong, Dec. 19, 1984, P.R.C.- U.K., 23 I.L.M. 1366.

United Nations. 1976. International Covenant on Civil and Political Rights adopted and opened for signature, ratification and accession by General Assembly resolution 2200A (XXI) of 16 December 1966 entry into force 23 March 1976, in accordance with Article 49.

\section{Dr Vesna B. Ćorić}

Viši naučni saradnik, Institut za uporedno pravo, Beograd, Srbija

e-mail:vesnacoric@yahoo.com

\section{Dr Fernanda F. Fernandez Jankov}

Pravni fakultet, Univerzitet Sao Paolo, Brazil

Fernandez\&Jankov Legal Intelligence, Brazil, Portugalija, Srbija

e-mail: fernandez.jankov@fernandezjankov.eu

\section{AUTONOMIJA HONG KONGA NA OSNOVU PRINCIPA „JEDNA DRŽAVA, DVA SISTEMA“: PREISPITIVANJE KONCEPTA MEĐUNARODNOPRAVNE OBAVEZE}

\author{
Sažetak
}

Zakon Narodne Republike Kine o nacionalnoj bezbednosti u Specijalnoj administrativnoj regiji Hong Kong, koji je usvojen u junu 2020. godine, izazvao je veliko negodovanje u stručnoj javnosti. Činjenica da je usvajanju ovog zakona prethodilo više 
neuspelih pokušaja donošenja propisa koji bi regulisali osetljiva pitanja nacionalne bezbednosti u Hong Kongu svakako je doprinela interesovanju koje je novi zakon izazvao. Planirani zakon nije donet uprkos pokušajima za vreme kolonijalne britanske uprave, kao i nakon toga, 2003. godine. Autorke u radu najpre iznose postojeće kritike u pogledu njegove nezakonitosti, koje se upućuju nedavno usvojenom zakonu. Svesne istorijske dimenzije problema, autorke se upuštaju u analizu promene položaja Hong Konga i značaja koji je data promena imala za regulisanje pitanja nacionalne bezbednosti. Nakon ukazivanja na nedovoljnu sistematičnost kritika koje su izložene u naučnim i stručnim krugovima, autorke pristupaju temeljnoj analizi usklađenosti ovog zakona sa izvorima međunarodnog prava koristeći prevashodno dogmatski metod. U zaključnom delu rada autorke ukazuju na uočene nezakonitosti posvećujući posebnu pažnju pitanju da li je postojećim zakonom narušen princip ,jedna država, dva sistema“.

Ključne reči: novi zakon Narodne Republike Kine o nacionalnoj bezbednosti u Specijalnoj administrativnoj regiji Hong Kong, Zajednička deklaracija, međunarodno pravo, ljudska prava, Međunarodni pakt o građanskim i političkim pravima.

Received: 9. 2. 2021.

Revised: 30. 3. 2021.

Accepted: 31. 3. 2021. 